\title{
Assessment of the prevalence of iodine deficiency disorders among primary school children in Cairo
}

Nawal A. El Sayed,' Hanaa M. Ismail,'2 Mohamed A. Hussein ${ }^{3}$ and Abdel Rahman A. Kamel'

$$
\begin{aligned}
& \text { تقدير معلد انتشار اضطرابات موز اليود بين تلايذ الملارس الابتدائية بالقامرة }
\end{aligned}
$$

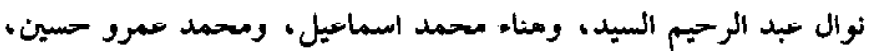

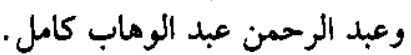

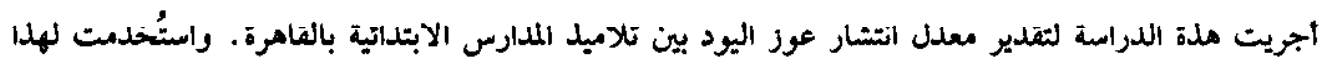

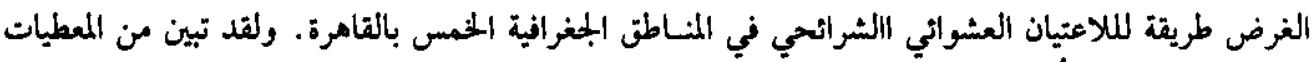

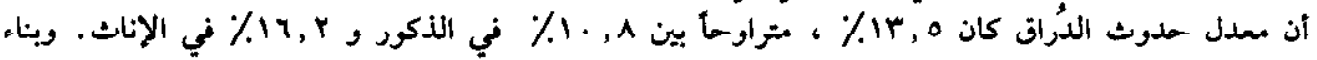

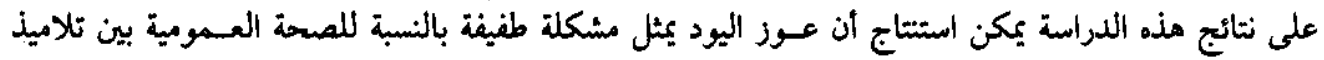

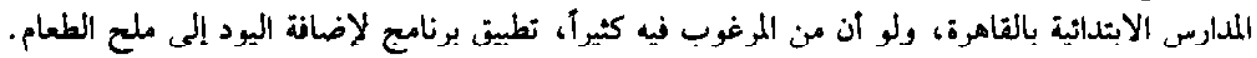

This study was done to assess the prevalence of iodine deficiency (ID) among primary schoolchildren in Cairo. A stratified random sampling technique covering the five geographic zones of Cairo was used. Data revealed that the goitre rate was $13.5 \%$; being $10.8 \%$ among males and $16.2 \%$ among females. Prevalence among females was higher than that of males in all categories. Based on the data found by this study, it can be concluded that ID constitutes a mild public health problem among Calro primary schoolchlidren, and a salt iodization programme is highly recommended.

Evaluation de la prévalonce des troubles dus à une carence en lode chez les floves des 6́coles primaires au Caire

Cette étude a été réalisée pour évaluer la prévalence de la carence en jode chez les élèves des écoles primaires au Caire. On a utilisé une technique de sondage stratifié couvrant les cinq zones géographiques du Caire. Les données ont révélé que le taux de prévalence du goitre était de $13,5 \%: 10,8 \%$ chez les garçons et $16,2 \%$ chez les filles. La prévalence chez les filles était toujours plus élevée que chez les garçons, toutes catégories confondues. On peut conclure des résultats de cette étude que la carence en iode constitue un léger problème de santé publique chez les écoliers du cycle primaire au Caire, et un programme d'iodation du sel est vivement recommandé.

'Professor of Nutrition, High Institute of Public Health, Alexandria University, Egypt; ${ }^{2 P r o f e s s o r}$ of Food Analysis, High Institute of Public Health, Alexandria University; " $P$ Professor of Nutrition, Nutrition Institute, Miniotry of Health, Cairo, Egypt; «Nutrition Spocialist, Nutrition institurte, Ministry of Hoalth, Cairo.

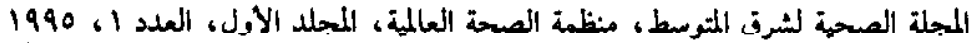




\section{Introduction}

lodine deficiency is recognized as the most important preventable cause of mental defect in the world today. Communities living in an iodine-deficient environment face a major block to their human and social development. Correction of iodine deficiency is indicated as a major contribution to development [1]. In the Eastern Mediterranean Region (EMR) of WHO at least 10 of the 22 Member States (Afghanistan, Egypt, Islamic Republic of Iran, Iraq, Libyan Arab Jamahiriya, Lebanon, Pakistan, Syrian Arab Republic, Sudan and Tunisia) have high to alarming rates of prevalence of goitre in certain areas [2].

Nutrition studies done all over Egypt in the past 60 years suggest the endemicity of goitre in certain areas, especially in the New Valley, in south central Egypt [3], and contradictory figures about its prevalence in other areas [4]. That is why this study was conducted; and to gather recent information about the current status of iodine nutrition and the magnitude and scverity of iodine deficicney among primary school children in Cairo.

\section{Subjects}

This study was carried out on a sample selected from governmental* primary school children (both sexes) in Cairo Governorate between Oetober 1990 and March 1991.

Stratified random sampling technique was used to select the study sample. Cairo is divided into five geographic zones: North, South, East, West and Central. From each zone two schools were randomly selected (only one school from East Cairo). School selection was done by the help of CAPMAS (Central Agency of Population Mobilization and Sta-

*Private schools were not included for administrative reasons. tistics) and the Statistics Department of the Ministry of Education. Then one class from each school grade was randomly chosen. A total sample of 1648 schoolchildren from the selected nine schools (forming about $0.8 \%$ of the total Cairo primary school population) constituted the subjects of the study.

\section{Methods}

\section{Goitre survey}

Every child in each class sampled was examined. The required data were collected through a questionnaire. Personal features were recorded. Examination of the thyroid gland was by palpation procedure according to criteria endorsed by the World Health Organization and ICCIDD (International Council for the Control of Iodine Deficiency Disorders) [5].

Classification of goitre size in this system is as follows:

\section{Grade Description}

0 No goitre

1A Thyroid lobes larger than ends of thumbs

1B Thyroid enlarged. visible with head tilted back

2 Thyroid enlarged, visible with neck in normal position

3 Thyroid greatly enlarged, visible from about 10 metres

Grades 2 and 3 are collectively called visible goitre.

\section{Determination of urinary lodine}

A subsample of 171 children ( 99 cases with 72 classmates as control) was chosen to conduct the urinary iodine determination. Untimed (casual) urine samples were taken from each child in the subsample. To each urine sample a few drops of tormalin were added and then kept refrigerated till the time of chemical analysis. Iodine in urine was 
determined based on the method of Moxon and Dixon [6] and HPLC (high pressure liquid chromatography) quantification of iodine.

\section{Results}

\section{Goltre prevalence}

Table 1 illustrates the distribution of the total sample of Cairo schoolchildren examined according to age, sex and geographical zone. It is observed that the modal age $(22.76 \%$ of the sample) was 8 years. Males formed $51.2 \%$ and females $48.8 \%$ of the total sample. The highest number of children examined was in South Cairo (23.4\%).

Table 2 and Fig. 1 illustrate the prevalence of goitre among the Cairo schoolchildren examined according to geographical zone and

Table 1 Distribution of the total sample of Cairo schoolchildren examined according to age, sex and geographical zono, 1000-1001

\begin{tabular}{|c|c|c|c|c|c|c|c|c|c|c|c|c|c|c|}
\hline \multirow[t]{2}{*}{ Zone: } & \multicolumn{2}{|c|}{ North } & \multicolumn{2}{|c|}{ South } & \multicolumn{2}{|c|}{ East } & \multicolumn{2}{|c|}{ West } & \multicolumn{2}{|c|}{ Central } & \multicolumn{2}{|c|}{ Total } & \multicolumn{2}{|c|}{ Grand total } \\
\hline & $M$ & $\boldsymbol{F}$ & $\mathbf{M}$ & $\mathbf{F}$ & $\mathbf{M}$ & $F$ & $\mathbf{M}$ & $\mathbf{F}$ & $\mathbf{M}$ & $\mathbf{F}$ & $M$ & $\mathbf{F}$ & No. & $\%$ \\
\hline \multicolumn{15}{|l|}{ Age } \\
\hline 6 & 5 & 8 & 5 & 1 & - & - & 2 & 6 & 4. & 2 & 16 & 17 & 33 & 2.00 \\
\hline $\begin{array}{l}7 \\
8\end{array}$ & $\begin{array}{l}33 \\
64\end{array}$ & $\begin{array}{l}25 \\
43\end{array}$ & $\begin{array}{l}39 \\
49\end{array}$ & $\begin{array}{l}33 \\
44\end{array}$ & $\begin{array}{l}20 \\
26\end{array}$ & $\begin{array}{l}18 \\
21\end{array}$ & $\begin{array}{l}30 \\
40\end{array}$ & $\begin{array}{l}38 \\
24\end{array}$ & $\begin{array}{l}43 \\
35\end{array}$ & $\begin{array}{l}33 \\
29\end{array}$ & $\begin{array}{l}165 \\
214\end{array}$ & $\begin{array}{l}147 \\
161\end{array}$ & $\begin{array}{l}312 \\
375\end{array}$ & $\begin{array}{l}18.93 \\
22.76\end{array}$ \\
\hline 9 & 25 & 38 & 38 & 43 & 25 & 16 & 34 & 28 & 32 & 44 & 154 & 160 & 314 & 19.05 \\
\hline 10 & 35 & 42 & 26 & 46 & 17 & 21 & 22 & 37 & 32 & 33 & 132 & 179 & 311 & 18.87 \\
\hline 11 & 30 & 20 & 40 & 30 & 24 & 18 & 31 & 31 & 20 & 24 & 145 & 131 & 270 & 10.75 \\
\hline $12-13$ & 2 & - & - & - & 1 & 1 & 11 & 9 & 3 & - & 17 & 10 & 27 & 1.64 \\
\hline Total & 194 & 184 & 197 & 188 & 113 & 95 & 170 & 173 & 169 & 165 & 843 & 805 & 1648 & 100.00 \\
\hline
\end{tabular}

$M=$ males; $F=$ females

Table 2 Prevalence of goltre among Cairo schoolchildren according to geographlcal zone and sex, 1990-1991

\begin{tabular}{|c|c|c|c|c|c|c|}
\hline \multirow[t]{2}{*}{ Bex } & \multicolumn{2}{|c|}{ Male } & \multicolumn{2}{|c|}{ Female } & \multicolumn{2}{|c|}{ Total } \\
\hline & No. & $\%$ & No. & $\%$ & No. & $\%$ \\
\hline \multicolumn{7}{|l|}{ Zone* } \\
\hline North & \multicolumn{2}{|c|}{$n=194$} & \multicolumn{2}{|c|}{$\begin{array}{c}51 \quad 27.72 \\
n=184\end{array}$} & \multicolumn{2}{|c|}{$\begin{array}{c}104 \\
n=378\end{array}$} \\
\hline South & \multicolumn{2}{|c|}{$n=197$} & \multicolumn{2}{|c|}{${ }_{n=188}^{13.30}$} & \multicolumn{2}{|c|}{$\begin{array}{c}41 \quad 10.65 \\
n=385\end{array}$} \\
\hline East & \multicolumn{2}{|c|}{$n=113$} & \multicolumn{2}{|c|}{$\begin{array}{c}16 \\
n=95\end{array}$} & \multicolumn{2}{|c|}{$\begin{array}{c}26 \\
n=208\end{array}$} \\
\hline West & \multicolumn{2}{|c|}{${ }_{n=170}^{5.29}$} & \multicolumn{2}{|c|}{${ }_{n=173}^{11.56}$} & \multicolumn{2}{|c|}{$29=3.45$} \\
\hline Middle & \multicolumn{2}{|c|}{$3^{n}=169$} & \multicolumn{2}{|c|}{${ }_{n=19}^{11.52}$} & \multicolumn{2}{|c|}{${ }^{22} n=334.59$} \\
\hline Total & & $n=843$ & $\begin{array}{r}101 \\
n\end{array}$ & $n=805$ & $\begin{array}{r}222 \\
n=\end{array}$ & $\begin{array}{l}10.47 \\
648\end{array}$ \\
\hline
\end{tabular}

المجلة الصحية لشرت المتوسط، منظمة الصحة العالمية، المجلد الاول، العدد 1، 1940 


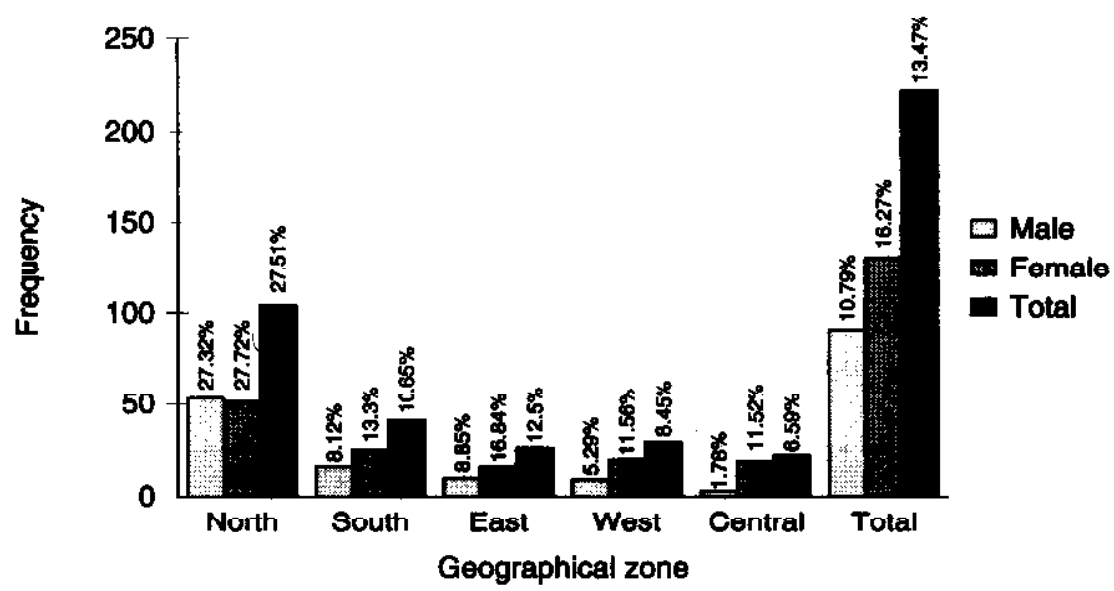

Figure 1 Provalence of goltre among the Calro schoolchlldren examined according to geographlcal zone and sex

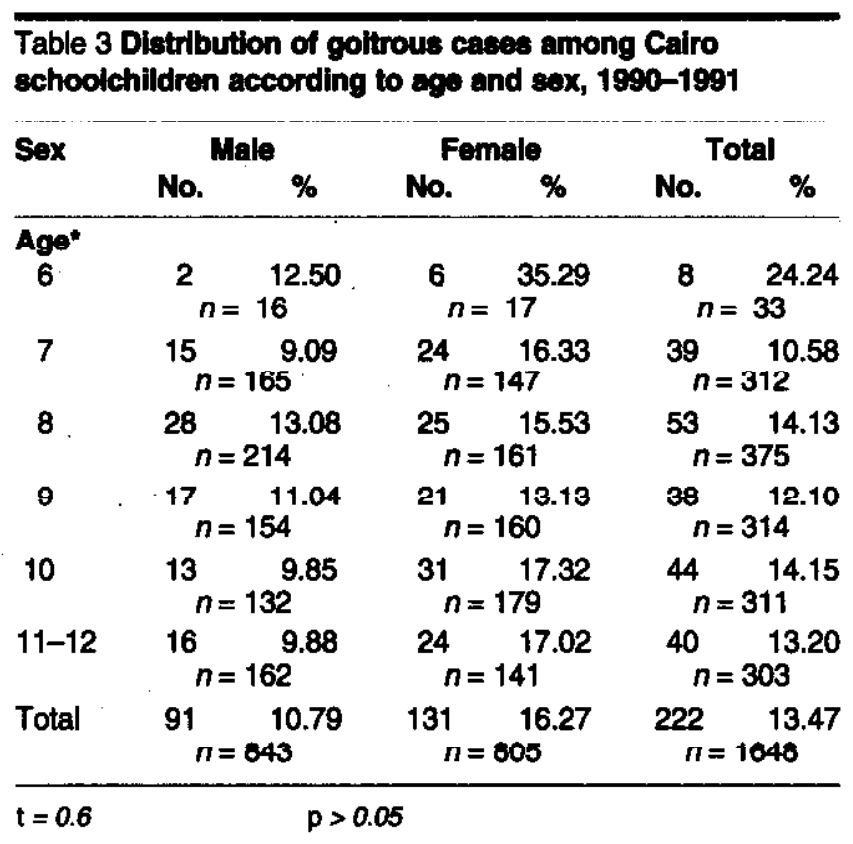

sex. It is quite clear that the highest prevalence was in North Cairo (27.51\%) and the lowest was in Central Cairo (6.59\%). Goitre was always more prevalent in females than in males. The total goitre rate was $13.47 \%$, being $10.8 \%$ among males and $16.2 \%$ among females. The difference in goitre prevalence per zone was statistically significant. $\chi_{4}^{2}=12.4, p<0.05$.

Table 3 exhibits the distribution of goitrous cases among the Cairo schoolchildren exam- 
Table 4 Distribution of goltrous cases according to goltre grade, sex, and geograpnical zona, 1990-1991

\begin{tabular}{|c|c|c|c|c|c|c|c|c|}
\hline \multirow[t]{2}{*}{ Zone } & \multicolumn{2}{|c|}{ Grade 1A } & \multicolumn{2}{|c|}{ Grade 1B } & \multicolumn{2}{|c|}{ Grade 2} & \multicolumn{2}{|c|}{ Total } \\
\hline & $\mathbf{M}$ & $\mathbf{F}$ & $\mathbf{M}$ & $\mathbf{F}$ & $\mathbf{M}$ & $\boldsymbol{F}$ & $\mathbf{M}$ & $\mathbf{F}$ \\
\hline \multicolumn{9}{|l|}{ North } \\
\hline $\begin{array}{l}\text { No. } \\
\%\end{array}$ & $\begin{array}{c}15 \\
46.87\end{array}$ & $\begin{array}{c}12 \\
25.00\end{array}$ & $\begin{array}{c}38 \\
64.41\end{array}$ & $\begin{array}{c}38 \\
46.34\end{array}$ & - & $\begin{array}{l}1 \\
-\end{array}$ & $\begin{array}{c}\mathbf{5 3} \\
\mathbf{5 8 . 2 4}\end{array}$ & $\begin{array}{c}51 \\
38.93\end{array}$ \\
\hline \multicolumn{9}{|l|}{ South } \\
\hline $\begin{array}{l}\text { No. } \\
\%\end{array}$ & $\begin{array}{c}4 \\
12.50\end{array}$ & $\begin{array}{c}7 \\
14.58\end{array}$ & $\begin{array}{c}12 \\
20.34\end{array}$ & $\begin{array}{c}18 \\
21.95\end{array}$ & - & - & $\begin{array}{c}16 \\
17.58\end{array}$ & $\begin{array}{c}25 \\
19.09\end{array}$ \\
\hline \multicolumn{9}{|l|}{ East } \\
\hline $\begin{array}{l}\text { No. } \\
\% \\
\text { West }\end{array}$ & $\begin{array}{c}5 \\
15.75\end{array}$ & $\begin{array}{c}4 \\
8.33\end{array}$ & $\begin{array}{c}5 \\
8.48\end{array}$ & $\begin{array}{c}12 \\
14.63\end{array}$ & $\begin{array}{l}- \\
-\end{array}$ & - & $\begin{array}{c}10 \\
10.99\end{array}$ & $\begin{array}{c}16 \\
12.21\end{array}$ \\
\hline $\begin{array}{l}\text { No. } \\
\%\end{array}$ & $\begin{array}{c}6 \\
18.75\end{array}$ & $\begin{array}{c}11 \\
22.92\end{array}$ & $\begin{array}{c}3 \\
5.08\end{array}$ & $\begin{array}{c}9 \\
10.98\end{array}$ & - & - & $\begin{array}{c}9 \\
9.89\end{array}$ & $\begin{array}{c}20 \\
15.50\end{array}$ \\
\hline \multicolumn{9}{|l|}{ Central } \\
\hline $\begin{array}{l}\text { No. } \\
\%\end{array}$ & $\begin{array}{c}2 \\
6.25\end{array}$ & $\begin{array}{c}14 \\
29.17\end{array}$ & $\begin{array}{c}1 \\
1.69\end{array}$ & $\begin{array}{c}5 \\
6.10\end{array}$ & - & - & $\begin{array}{c}3 \\
3.30\end{array}$ & $\begin{array}{c}19 \\
14.50\end{array}$ \\
\hline \multicolumn{9}{|l|}{ Total } \\
\hline $\begin{array}{l}\text { No. } \\
\% \\
\text { Grand total }\end{array}$ & $\begin{array}{c}32 \\
100\end{array}$ & $\begin{array}{c}48 \\
100\end{array}$ & $\begin{array}{c}59 \\
100\end{array}$ & $\begin{array}{c}82 \\
100\end{array}$ & $\overline{0}$ & $\begin{array}{c}1 \\
100\end{array}$ & $\begin{array}{c}91 \\
100\end{array}$ & $\begin{array}{l}131 \\
100\end{array}$ \\
\hline $\begin{array}{l}\text { No. } \\
\%\end{array}$ & $\begin{array}{c}80 \\
36.00\end{array}$ & $\begin{array}{c}41 \\
63.50\end{array}$ & $\begin{array}{c}1 \\
0.05\end{array}$ & $\begin{array}{l}222 \\
100\end{array}$ & & & & \\
\hline
\end{tabular}

Grade for sex $\chi^{2}=0.071 ; \quad$ grade for zone $\chi_{4}^{2}=24.534$

not fignificent $\quad$ teignifioant, $p<0.06$

ined according to age and sex. As is evident from the table the highest prevalence was at age $6(24.24 \%)$ and the lowest was at age 7 $(10.58 \%)$. For males, the age of highest frequency was 8 years $(13.08 \%)$ and the lowest was 7 years $(9.09 \%)$. For females they were 6 years $(35.29 \%)$ and 9 years $(13.13 \%)$ respectively. No significant difference could be detected for goitre prevalence by age or sex.

Table 4 indicates the distribution of goitrous cases according to goitre grade, sex and geographical zone. From the table, it is clear that no grade 3 goitre was detected in the survey. Only one female case of grade 2 goitre was observed, in North Cairo. Grade 1B goitre recorded a higher prevalence ( $63.5 \%)$ among examined children than grade $1 \mathrm{~A}(36 \%)$. The highest frequency of goitre (all grades) was in
North Cairo, while the lowest was in Central Cairo. The male:female ratio was about 1:1.5. The difference in the goitre grades in different Cairo zones is significant, $\chi_{4}^{2}=24.534$, with $p<0.05$, but that between males and females is not significant: $\chi^{2}=0.0715$.

\section{Urinary excretion of lodine of the studled subsamples}

Table 5 illustrates the distribution of cases and controls according to age, sex and mean urinary excretion in $\mu \mathrm{g} / \mathrm{dl}$. From the table, it is observed that the pattern of urinary iodine excretion by ID cases compared with their controls is inconsistent. Generally, males recorded slightly higher values than females. The older the child, the lower the value of urinary iodine, especially in ID cases. The mean total urinary 
Table 5 Distribution of cases and controls accondlng to age, sex, and mean urimary iudine excretion in $\mu$ gld, 1990-1991

\begin{tabular}{rrccccccc}
\hline \multicolumn{1}{l}{ Age in years } & $\mathbf{6}$ & $\mathbf{7}$ & $\mathbf{8}$ & $\mathbf{9}$ & 10 & $11-12$ & total \\
\hline Male & cases $n=38$ & $8.5 \pm 0.0$ & $6.5 \pm 2.5$ & $5.5 \pm 1.6$ & $4.1 \pm 2.3$ & $4.6 \pm 1.9$ & $4.7 \pm 1.3$ & $5.3 \pm 2.2$ \\
& controls $n=27$ & $9.0 \pm 0.0$ & $5.2 \pm 0.9$ & $4.4 \pm 1.3$ & $5.6 \pm 2.2$ & $4.7 \pm 2.6$ & $5.6 \pm 2.4$ & $5.4 \pm 2.0$ \\
& $t$ value & 0.00 & 1.10 & 1.31 & 1.28 & 0.07 & 0.82 & 0.00 \\
Female cases $n=61$ & $6.1 \pm 1.9$ & $3.8 \pm 1.2$ & $3.3 \pm 1.7$ & $4.6 \pm 1.3$ & $5.1 \pm 5.0$ & $5.0 \pm 1.1$ & $4.6 \pm 2.8$ \\
& controls $n=45$ & $4.8 \pm 0.1$ & $5.3 \pm 1.2$ & $5.1 \pm 2.4$ & $4.7 \pm 1.1$ & $5.2 \pm 1.2$ & $4.6 \pm 1.7$ & $5.0 \pm 1.4$ \\
& $t$ value & 0.91 & $2.93^{*}$ & 1.71 & 0.19 & 0.06 & 0.62 & 0.89 \\
Total & cases $n=99$ & $6.9 \pm 1.9$ & $5.1 \pm 2.3$ & $4.2 \pm 2.0$ & $4.4 \pm 1.7$ & $4.9 \pm 4.3$ & $4.8 \pm 1.2$ & $4.8 \pm 2.6$ \\
& controls $n=72$ & $6.9 \pm 2.4$ & $5.3 \pm 1.1$ & $4.7 \pm 1.8$ & $5.1 \pm 1.6$ & $5.1 \pm 1.6$ & $5.0 \pm 1.9$ & $5.2 \pm 1.6$ \\
& $t$ value & 0.00 & 0.32 & 0.67 & 1.27 & 0.16 & 0.35 & 1.17 \\
\hline
\end{tabular}

significant $\mathrm{p}<0.05$

Table 6 Distribution of Calro schooichlldren by goltre grade, sex, and mean urinary iodine excretion

\begin{tabular}{|c|c|c|c|c|}
\hline \multirow[b]{2}{*}{ Grade } & \multicolumn{2}{|c|}{ Sex } & \multirow[b]{2}{*}{ total } & \multirow[b]{2}{*}{$t$ value } \\
\hline & males & females & & \\
\hline & $n-66$ & $n-106$ & $n-171$ & \\
\hline 0 & $\begin{array}{c}5.5 \pm 2.0 \\
n=27\end{array}$ & $\begin{array}{c}5.0 \pm 1.4 \\
n=45\end{array}$ & $\begin{array}{c}5.2 \pm 1.6 \\
n=72\end{array}$ & 1.25 \\
\hline $1 \mathrm{~A}$ & $\begin{array}{c}5.3 \pm 1.4 \\
n=15\end{array}$ & $\begin{array}{c}5.0 \pm 3.0 \\
n=21\end{array}$ & $\begin{array}{c}5.1 \pm 3.2 \\
n=36\end{array}$ & 0.28 \\
\hline $1 B$ & $\begin{array}{c}5.1 \pm 2.3 \\
n=23\end{array}$ & $\begin{array}{c}4.3 \pm 1.5 \\
n=40\end{array}$ & $\begin{array}{c}4.6 \pm 2.0 \\
n=63\end{array}$ & 1.67 \\
\hline Total & $\begin{array}{c}5.3 \pm 2.0 \\
n=65\end{array}$ & $\begin{array}{c}4.7 \pm 2.2 \\
n=106\end{array}$ & $\begin{array}{c}5.0 \pm 2.2 \\
n=171\end{array}$ & 1.79 \\
\hline
\end{tabular}

iodine value for goitrous children, which was $4.8 \pm 2.6 \mu \mathrm{g} / \mathrm{dl}$, was insignificantly lower than that of the controls, which was $5.2 \pm 1.6 \mu \mathrm{g} / \mathrm{dl}$.

Table 6 and Fig. 2 show distribution of the children studicd according to goitre grade, sex and mean urinary iodine excretion in $\mu \mathrm{g} / \mathrm{dl}$. From the table, it is evident that urinary iodine values decrease with increase in goitre size (5.2 $\pm 1.6,5.1 \pm 3.2$ and $4.6 \pm 2 \mu \mathrm{g} / \mathrm{dl}$ for grades $0,1 \mathrm{~A}$ and $1 \mathrm{~B}$ respectively). It is also clear that males excreted more iodine in their urine than females. These differences are statistically insignificant.

\section{Discussion}

Working towards the goal of eliminating IDD as part of achieving child health and development goals for the year 2000 , surveillance activities can provide a quantitative basis for assessing progress towards these targets. One of the fundamental purposes of IDD surveillance is to determine the magnitude and distribution of IDD within a population to develop correction programmes and to stimulate action for the allocation of resources for IDD elimination.

The present study was conducted to assess the prevalence of goitre (as an indicator for IDD) in Cairo Governorate.

A sample of 1648 (843 males and $850 \mathrm{fe}$ males) primary schoolchildren aged 6-12 years was selected from nine public schools located in five different geographical areas of Cairo by stratified random method.

Goitre is arbitrarily defined to be endemic in an area if more than $10 \%$ of the population of schoolchildren aged 6-12 years are goitrous.

Very recently $[I I]$, the cut-off point of $10 \%$ was revised downward because it was found that goitre prevalence rates between $5 \%$ and $10 \%$ may be associated with a range of abnormalities, including subnormal circulating 
levels of thyroid homones and elevation of thyroid stimulating hormone (TSH) in the population, clearly representing a public concern.

The total goitre rate (TGR) recorded in this study was $13.5 \%$ (10.8\% in males and $16.3 \%$ in fernales), clearly lighlier than that reported by the Cairo Nutrition Institute in 1992-5.2\% among primary schoolchildren examined in Cairo [4]. This obvious difference between the two rates of goitre prevalence may be attributed to the variability in sampling methods, sample size and interobserver variations. The higher prevalence rate reported in this study may be explained by the results of urinary excretion of iodine and the larger sample size covered.

In 1962 Abdou et al. [7] reported a goitre prevalence rate of $17.8 \%$ among females and $1.7 \%$ among males in Cairo schoolchildren aged 7-19 years old.

In 1975 Amin et al. [ 8 ] found that $13.3 \%$ of Cairo schoolchildren aged $6-18$ years old were goitrous.

The present study showed a goitre prevalence rate comparable with that reported in
Port Sudau [7], a coastal rcgion in the Sudan, among examined schoolchildren (13.5\%).

In the present study goitre affected both sexes, being higher in females. Figures obtained did not show a significant difference between males and females regarding TGR in Cairu ( $10.8 \%$ in males and $16.3 \%$ in feruales). This observation is also reported in many recent studies [10].

By region, if the sample had been chosen by proportionate allocation, the unequal number of examined children may be overcome, but due to constraints mentioned earlier, this technique could not be followed. The highest prevalence rate recorded was in North Cairo, while the lowest was in Central Cairo $27.5 \%$ and $6.6 \%$ respectively). There is a highly significant difference between areas in goitre prevalence $\left(\chi_{4}^{2}=24.534\right.$ and $\left.p<0.05\right)$. This significant difference in such a small geographical area (Cairo) may indicate the implication of cotactors other than iodine deticiency in this goitrogenesis. This is substantiated by higher rates of iodine excretion in North Cairo schoolchildren, probably due to higher consumption of goitrogens.

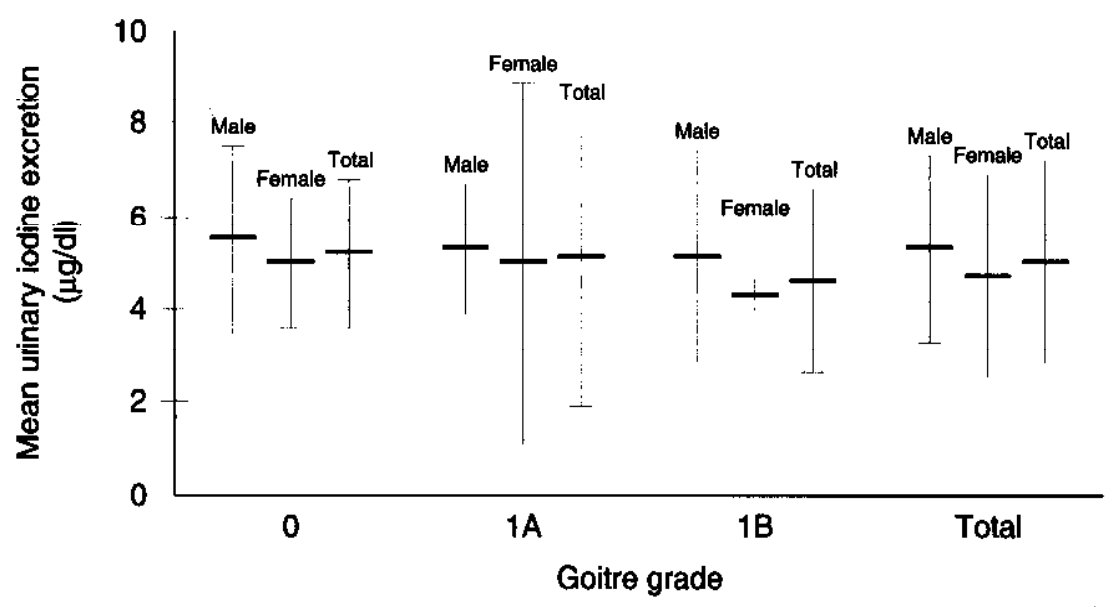

Figure 2 Distribution of the studied children according to goltre grade, sex and mean urinary excretion in $\mu g / d l$

المجلة الصحية لثرت المتوسط، منظمة الصهة العالمية، المجلد الأول، العدد 1990، 
Considering goitre prevalence by grade; $36 \%$ of cases had grade 1 A goitre, $60 \%$ of them female. Only one female case, in North Cairo, had grade 2 goitre.

The classification method of goitre grades used in this study was based on the 1990 criteria of WHO [5]. A modification of this system has been proposed by WHO, UNICEF and ICCIDD [11]: combine grades $1 \mathrm{~A}$ and $1 \mathrm{~B}$ together and grades 2 and 3 intu a secund grade. However, this proposed classification may hinder the impact of IDD control programmes when goitres reduce in size from grade $1 B$ to grade $1 \mathrm{~A}$ or from grade 3 to grade 2 .

\section{Urinary excretion of iodine}

The rate of iodine excretion is a good and reliable index for estimating iodine intake [5].

The urinary iodine excretion in a casual urine sample is a valuable index for evaluating the iodine supply of population The population sample size should be at least 50-100 because this number, statistically, allows for changes in urinary iodine concentration arising from possible differences in dilution [12].

The data of the present study revealed that the mean iodine excretion of the whole sample was $5.0 \pm 2.2 \mu \mathrm{g} / \mathrm{dl}$ reflecting a state of mildly severe iodine deficiency. Cases and controls reported comparable figures $(4.8 \pm 2.6$ and $5.2 \pm 1.6 \mu \mathrm{g} / \mathrm{dl}$ respectively). Males excreted slightly more iodine in urine than females. Grade 1B goitrous children excreted less iodine in urine $(4.6 \pm 2.0 \mu \mathrm{g} / \mathrm{dl})$ than grade $1 \mathrm{~A}$ children $(5.1 \pm 3.2 \mu \mathrm{g} / \mathrm{dl}$ ). Grade 0 (nongoitrous control children) reported a slightly higher figure $5.2 \pm 1.6 \mu \mathrm{g} / \mathrm{dl}$ ). This indicates that iodine excretion may be inversely related to the size of goitre, as suggested by other studies [12].

Male and female children in North Cairo reported higher figures of iodine excretion $(6.1 \pm 1.8$ and $5.3 \pm 2.0 \mu \mathrm{g} / \mathrm{dl}$ respectively) than in other areas. The highest urinary iodine excretion was recorded in North Cairo (5.7 \pm
$1.9 \mu \mathrm{g} / \mathrm{dl})$ while the lowest was in Central Cairo $(3.9 \pm 1.2 \mu \mathrm{g} / \mathrm{dl})$.

This finding further supports a previous conclusion that the wide variation in goitre prevalence in different Cairo zones may be due to factors, dietary or nondietary, other than iodine deficiency.

A 1993 study on goitre conducted in Morocco [13] found the median value for urinary iodine in endemic areas was $1.8 \mu \mathrm{g} / \mathrm{dl}$ and 2.4 $\mu \mathrm{g} / \mathrm{dl}$ for cases and controls respectively in comparison to $11.7 \mu \mathrm{g} / \mathrm{dl}$ in Casablanca (where goitre is not endemic). However, the study's use of the HPLC in analysing urinary iodine (a very sensitive method) and the possible mole of goitrogens may play a role in the difference between figures in this study and that of Morocco.

\section{Conclusions}

From the study it may be concluded that:

- IDD (as indicated by goitre prevalence) is of mild severity in Cairo Governorate. This finding confirms previous studies conducted in Cairo and is substantiated by a mean urinary jodine excretion of around $5.0 \mu \mathrm{g} / \mathrm{dl}$.

- Female cases constituted $59 \%$ of total cases. and their number was higher than that of males in all areas except in North Cairo. Iodine deficiency may be sex linked.

- The highest prevalence of goitre was in North Cairo (27.51\%) and the lowest was in Central Cairo (6.59\%). The difference in goitre prevalence in different areas is statistically significant. This may indicate that factors other than iodine deficiency play a part in goitrogenesis.

- Grade 1B goitre was more prevalent (63.5\%) than grade $1 \mathrm{~A}(36 \%)$.

- Observations indicated that goitre may be more prevalent in lower socioeconomic levels. 


\section{Recommendations}

Based on data of the present study, the following recommendations are suggested:

- An iodization programme is needed to combat IDD, per WHO recommendations and for the benefit of coming generations.
- Further studies on larger saruples frum all educational zones may be needed to confirm the status of IDD in Cairo.

- A household survey for goitre is needed to detect the presence of familial goitre and to reflect the impact of socioeconomic status on goitre.

\section{References}

1. Hetzel BS. The control of iodine deficiency. American Joumal of Public Health, 1993, 83(4).

2. lodine deficiency disorders, a strategy for control in the EMR. Alexandria, World Health Organization, Easterm Mediterranean Regional Office, 1990 (WHO/EMRO Technical Publication No. 16).

3. Abdou IA. The nutritional state in New Valley 1959-1905 (In Arablc).

4. Report on prevalence of IDD among school children in Egypt. Cairo, Egypt, Nutrition Institute/WHO, 1992.

5. ICCIDD/UNICEFMHO. A practical guide to the correction of iodine deficiency 1990. Manual No. 3.

6. Moxon RE, Dixon EJ. Semiautomatic method for the determination of total lodine in tood. Analyst, 1980, 105:344352.

7. Abdou IA et al. Incidence of nutritional deflciencles, goltre, and dental caries among school children in Cairo. Bulletin of the Nutrition Institute, Cairo, Egypt, 1968, 4(1):69-80.
8. Amin KS et al. Follow-up study of nutritional deficiencies among Cairo school children. Joumal of the Egyptian Public Health Assoclation, 1980, 55(5,6):254263.

9. Eltom $M$ et al. Endemic goiter in the Darfur reglon (Suclan). Acta Medica Scandinavica, 1984, 215:467-475.

10. Wolde GZ et al. Goitre in Ethiopia. British Joumal or Nutrition, 1993, 69(1):257-268.

11. Indicators for assessing IDDs and their control programmes. WHO/UNICEF/ ICCIDD Report, September 1993.

12. Bourdoux $P$ et al. A new look at old concepts in laboratory evaluation of endemic goiter. In Dunn JT et al. (eds.). Towards the eradication of endemic goiter, cretinism, and lodine deficiency. Washington DC, Pan American Health Organization, 1986 (PAHO Scientific Publication No. 502).

13. Aquaron $A$ et al. Endemic goiter in Morocco (Skoura-Toundoute areas in the high Atlas). Joumal of Endocrinological Investigation, 1993, 16(1):9-14. 